\title{
Manajemen Mutu Input \\ Kelompok Bimbingan Ibadah Haji Indonesia
}

\author{
Aep Kusnawan*, Arif Rahman, Dede Lukman, \& Encep Dulwahab \\ Fakultas Dakwah dan Komunikasi UIN Sunan Gunung Djati, Bandung \\ *Email: aep.kusnawan@uinsgd.ac.id
}

\begin{abstract}
Haij guidance group $(\mathrm{KBIH})$ in Indonesia, still limited to quantity and have been not yet met the quality. One indication of the lack of quality of the $\mathrm{KBIH}$ is the quality management of inputs, namely the applied inputs and inputs of expectation. With good input and good, it can produce an out put that as expected. This study aims to determine the quality management of pilgrimage inputs by $\mathrm{KBIH}$ in Indonesia, represented by three regions, West Java, DKI Jakarta and South Sumatra.. This case study with qualitative approach shows that quality management for one dimension of input, especially in KBIH has not met the quality management standard. Implementation and embodiment is still limited to ideas, wishful thinking, and not conceptualized well. The results of this study have an impact on how the quality management of KBIH input in Indonesia should be implemented, so that with good input, KBIH can improve the quality of Haij in Indonesia. This research suggest to KBIH to make Input as a starting point in a quality assurance process.
\end{abstract}

Keywords: Input; Quality Management; Hajj Guidance Group

\begin{abstract}
ABSTRAK
Kelompok Bimbingan Ibadah Haji (KBIH) di Indonesia masih sebatas kuantitas, belum memenuhi kualitas. Salah satu indikasinya yaitu kurangnya kualitas KBIH pada manajemen mutu input, baik input terapan maupun imput harapan. Dengan input yang baik dan bagus, maka bisa menghasilkan out put yang sesuai harapan. Penelitian ini menggambarkan manajemen mutu input penyelenggaraan haji oleh KBIH di Indonesia, yang diwakili tiga wilayah, Jawa Barat, DKI Jakarta dan Sumatera Selatan. Penelitian dengan metode studi kasus dan pendekatan kualitatif ini memperlihatkan bahwa manajemen mutu untuk satu dimensi input, khususnya di KBIH belum memenuhi standar manajemen mutu. Pelaksanaan dan perwujudannya masih sebatas ide, angan-angan, dan belum terkonsep dengan baik. Hasil penelitian ini berdampak pada bagaimana manajemen mutu input KBIH di Indonesia seharusnya diimplementasikan, sehingga dengan imput yang baik, KBIH bisa meningkatkan kualitas penyelenggaraan ibadah haji di Indonesia. Penelitian ini memberi saran kepada KBI agar menjadikan input menjadi starting point dalam sebuah proses jaminan mutu.
\end{abstract}

Kata Kunci: Input, Manajemen Mutu, Kelompok Bimbingan Ibadah Haji

\footnotetext{
* Tulisan ini pernah dipresentasikan di Seminar Nasional Dakwah, Bandung, 27-29 Oktober 2018
}

Diterima: Oktober 2017. Disetujui: Desember 2017. Dipublikasikan: Desember 2017 


\section{PENDAHULUAN}

Perkembangan KBIH di Indonesia setiap tahunnya menunjukkan jumlah yang terus meningkat. Kurang lebih ada $5000 \mathrm{KBIH}$ yang beroperasi. Keberadaan $\mathrm{KBIH}$ ini membantu pemerintah dalam penyelenggaraan ibadah haji, yang setiap tahun dilaksanakan dengan jumlah haji yang terus meningkat. Namun peningkatan jumlah pendaftar haji, belum sebanding dengan perolehan kuota haji dari pemerintah Arab Saudi. Masa tunggu rata-rata keberangkatan jemaah haji secara nasional mencapai 18 tahun. Lamanya masa tunggu ini juga dipicu pengurangan kuota haji sebanyak $20 \%$ dalam kurun waktu tiga tahun terakhir. Dampaknya, jemaah haji meningkat tajam hingga lebih dari 1,2 juta (Rokhmad, 2015: 20).

Tentu saja kondisi ini merupakan tugas berat yang harus diselesaikan oleh pemerintah dan KBIH. Tidak heran kalau di lapangan, KBIH ini terus berlomba meraih kepercayaan dan memenuhi kepuasan jemaah haji. Berbagai cara terus KBIH tingkatkan, baik dari segi kualitas pelayanan, bimbingan dan fasilitas lainnya agar bisa memuaskan para jemaahnya.

Berbagai upaya peningkatan kualitas KBIH mulai dari bimbingan sampai pelayanan khusus pun dilakukan. Hal ini sesuai dengan UU nomor 13 tahun 2008 pasal 1 ayat (2) yang menyatakan bahwa penyelenggaraan ibadah haji adalah rangkaian kegiatan pengelolaan pelaksanaan ibadah haji yang meliputi pembinaan, pelayanan, dan perlindungan kepada jemaah haji.

Penyelenggaraan ibadah haji terus ditingkatkan, baik dengan perencanaan yang lebih matang, evaluasi yang teratur secara reguler, dan penggunaan standar mutu yang benar-benar tinggi. Di antara standar mutu dalam meningkatkan kualitas penyelenggaraan ibadah haji, terutama manajemen yang dipakai KBIH ketika berprestasi di Indonesia, bisa menggunakan manajemen mutu. Dan salah satu dalam manajemen mutu, yaitu input mutu perangkat dan input mutu harapan. Mutu perangkat meliputi: struktur organisasi, peraturan perundang-undangan, deskripsi tugas, rencana, program, dan lain sebagainya. Sedangkan yang termasuk ke dalam input harapan bisa berupa visi, misi, tujuan dan sasaran yang ingin dicapai.

Berdasarkan hasil observasi pra riset ke lapangan, didapatkan beberapa catatan bahwa KBIH dengan input mutu harapan masih relatif di bawah ideal sebuah institusi, lembaga atau organisasi yang dianggap sehat dan profesional. Mulai dari struktur organisasi yang masih terkesan segala sesuatu dikerjakan oleh satu orang, kemudian ketidakjelasan tugas setiap para pengelola $\mathrm{KBIH}$, bahkan cenderung tergantung situasi dan kondisi, sementara rencana dan program banyak $\mathrm{KBIH}$ yang mengabaikan untuk merumuskan dan menuangkannya dalam bentuk tulisan atau moto-moto KBIH.

Kemudian hasil observasi pra riset mengenai input harapan, rata-rata tidak membuatnya kalau pun ada menginduk pada visi misi dan tujuan lembaga, organisasi yang sudah ada sebelumnya. Hal ini karena KBIH menginduk pada 
yayasan atau organisasi yang berdiri lebih dulu, seperti sekolah, pondok pesantren, dan lembaga keagamaan (Muhammadiyah, Nahdlatul Ulama, dan Persis) dengan basis jemaah yang banyak. Meskipun demikian, ada visi, misi dan tujuan informal yang ingin diwujudkannya ketika musim ibadah haji di tahun-tahun yang akan datang.

Terdapat banyak bukti yang memperlihatkan bagaimana peranan dan kontribusi manajemen mutu dalam meningkatkan kualitas dan performance lembaga, institusi dan organisasi. Misalnya hasil penelitian yang dilakukan oleh Esin Sadikoglu and Hilal Olcay (2014: 13), bahwa dengan manajemen mutu bisa meningkatkan performance perusahaan atau organisasi di mata konsumen atau publik, meningkatkan pelayanan sehingga pelanggan mendapatkan kepuasan yang tidak didapatkan di lembaga lain, dan peningkatan kualitas dan persebaran produk yang daerah yang lebih luas lagi.

Sementara hasil penelitian lain yang juga masih meneliti tema manajemen mutu, seperti hasil penelitian yang dilakukan Sri Nuryati (2017: 155), menunjukkan bahwa Evaluasi Implementasi Sistem Manajemen Mutu ISO 9001:2008 Puskesmas di Wilayah Kerja Dinas Kesehatan Kabupaten Sleman: Kebijakan reformasi birokrasi dengan penerapan SMM ISO 9001:2008 di puskesmas sangat menguntungkan Dinas Kesehatan Kabupaten Sleman. Dengan adanya sistem manajemen mutu, pembangunan fisik puskesmas menjadi lebih bagus dari semula. Berangkat dari keberhasilan ini pula, menjadi alasan kuat untuk merehabilitasi bangunan fisik semua puskesmas. Dengan kata lain, artinya manajemen mutu telah berhasil membantu dalam meningkatkan kualitas pelayaan kesehatan yang bisa didapatkan oleh masyarakat.

Penelitian lain yang menjadikan manajemen mutu sebagai alat untuk menganalisisnya bisa dilihat pada hasil penelitian Davood Gharakhani dan kawankawan (2013: 48), bahwa manajemen mutu meningkatkan keuntungan lembaga, organisasi, atau perusahaan baik dari sisi keuangan, brand atau penampilan perusahaan, meningkatkan inovasi-inovasi dalam produk dan pekerjaan dalam perusahaan, dan meningkatkan jumlah dan kualitas pelanggan.

Pada ketiga hasil penelitian di atas memperlihatkan bagaimana peran vital manajemen mutu dalam meningkatkan sebuah lembaga, perusahaan atau organisasi. Penggunaan manajemen mutu bisa memperlihatkan bagaimana kontribusinya dalam menunjang kinerja perusahaan, lembaga atau organisasi.

Meskipun ketiganya meneliti mengenai manajemen mutu, namun ada perbedaan antara ketiga hasil penelitian dengan penelitian ini. Ketiga penelitian di atas meneliti lebih kepada manajemen mutu secara umum, sementara penelitian ini lebih spesifik lagi, yaitu penelitian pada input manajemen mutu, khususnya input manajemen mutu di KBIH. Jadi penelitian ini jauh lebih spesifik lagi dari manajemen mutu yang sudah populer di dunia manajemen dan organisasi.

Penelitian ini bertujuan untuk mengetahui bagaimana input manajemen mutu di dalam sebuah KBIH di Indonesia. Dengan demikian dari hasil penelitian 
ini bisa mendapatkan gambaran sekaligus masukan mengenai bagaimana input yang bagus dan baik dalam pengelolaan sebuah lembaga yang bernama KBIH.

Untuk mencapai tujuan tersebut, penelitian ini menggunakan metode penelitian studi kasus. Studi kasus digunakan sebagai metode dalam penelitian ini dengan alasan bahwa penentuan ini bertujuan untuk menguraikan dan menjelaskan secara komprehesif mengenai berbagai aspek mengenai KBIH sebagai realitas yang unik, dengan maksud memenuhi dan menguji teori manajemen mutu yang ada, dengan cara mengobservasi dan menganalisis fenomena KBIH yang sebelumnya tidak diselidiki secara ilmiah, sekaligus memperbandingkannya (multiple-case) di antara beberapa kasus pengelolaan KBIH di Indonesia.

\section{HASIL DAN PEMBAHASAN}

Input adalah segala sesuatu yang harus tersedia karena dibutuhkan untuk keberlangsungannya proses. Maksud segala sesuatu adalah berupa sumber daya dan perangkat lunak, serta harapan-harapan sebagai pemandu bagi keberlangsungan proses. Input sumber daya meliputi sumber daya manusia dan sumber daya selebihnya (peralatan, perlengkapan, uang bahan-bahan, dan sebagainya).

Kesiapan input sangat diperlukan agar proses dapat berlangsung dengan baik. Dengan kata lain dapat disimpulkan bahwa tinggi rendahnya mutu imput dapat diukur dari tingkat kesiapan input, makin tinggi kesiapan input, makin tinggi pula mutu input tersebut. Maka proses pun akan berjalan dengan lebih baik lagi.

Adapun proses merupakan proses berubahnya sesuatu menjadi sesuatu yang lain. Sesuatu yang berpengaruh terhadap berlangsungnya proses disebut input, sedangkan sesuatu dari hasil proses disebut output. Proses dikatakan bermutu tinggi apabila pengkoordinasian dan penyerasian serta pemanduan input dilakukan secara harmonis, sehingga mampu menciptakan situasi yang menyenangkan (enjoyable learning), mampu mendorong motivasi dan minat, dan benar-benar mampu memberdayakan input.

Sementara manajemen mutu input KBIH yang menjadi objek penelitian ini, terdiri dari input calon jemaah haji, mulai dari kompetensi calon jemaah haji, tingkat penguasaan kompetensi penyelenggara yaitu $\mathrm{KBIH}$, rencana dan program $\mathrm{KBIH}$, standar mutu $\mathrm{KBIH}$, panduan-panduan yang dimiliki $\mathrm{KBIH}$ dalam menjalankan tugasnya atau mengoperasikan $\mathrm{KBIH}$, struktur organisasi, deskripsi tugas, dan visi misi sampai tujuan KBIH.

Berdasarkan data yang didapatkan di lapangan, hasil wawancara dan pengamatan, didapatkan beberapa informasi mengenai input manajemen mutu $\mathrm{KBIH}$ di Indonesia. Secara umum, mengenai input manajemen mutu KBIH itu terdiri dari input internal, yaitu input yang disiapkan terlebih dahulu oleh $\mathrm{KBIH}$ itu sendiri, dan input eksternal, artinya input yang datangnya dari luar, memasukkan 
bahan-bahan yang sudah ada di luar dalam melengkapi yang sudah ada di dalam KBIH.

Input internal dan eksternal ini sama halnya dengan istilah yang sudah populer, yaitu input perangkat dan input harapan. Input perangkat meliputi: struktur organisasi, peraturan perundang-undangan, deskripsi tugas, rencana, program, dan lain sebagainya. Sedangkan yang termasuk ke dalam input harapan bisa berupa visi, misi, tujuan dan sasaran yang ingin dicapai.

Mengawali manajemen mutu input KBIH dari kompetensi jemaah mengenai penyelenggaraan ibadah haji, bahwasannya pengetahuan dan wawasan jemaah haji relatif beragam. Ada jemaah haji yang sudah memahami dan mengetahui perihal penyelenggaraan ibadah haji. Untuk jemaah yang sudah memahami ini dikarenakan mereka adalah seorang ulama, kiai, orang yang pernah belajar dan mempelajari ibadah haji kemudian baru menunaikan ibadah haji.

Jemaah yang seperti ini tidak ada kendala dalam perjalanan manasik haji. Peran KBIH tinggal bagaimana persiapan mental, fisik, dan pelaksanaan di lapangan, baik di tanah air, tanah suci, dan kembali ke tanah air. Bahkan ada beberapa KBIH ketika ada jemaah seperti ini, akan dilibatkan dalam manasik haji, pelaksanaan haji, dan membantu meringankan beban dan tugas berat KBIH dalam penyelenggaraan ibadah haji.

Ada juga jemaah yang tidak tahu sama sekali mengenai penyelenggaraan ibadah haji. Ini memerlukan kerja keras dari KBIH. Bagaimana ketika manasik haji yang sudah tua sehingga susah memahami materi-materi manasik haji. Terlebih kalau jemaah itu pendidikannya rendah, usia sudah tua, dan susah berkomunikasi dengan bahasa selain bahasa daerahnya. Karena selain tidak tahu mengenai cara penyelenggaraan ibadah haji, para jemaah yang karakter seperti ini juga tidak pernah naik pesawat, boarding pass, bagaimana hidup dan tinggal di Timur Tengah yang secara bahasa dan budaya berbeda, dan ini membutuhkan kerja ekstra dari KBIH.

Selain kedua karakter jemaah tadi, ada juga karakter jemaah yang melek dengan pengetahuan dan wawasan ibadah haji, tetapi memiliki karakter yang unik sok tau, sok pintar, ingin dilihat orang lain, dan cenderung arogan. Dalam menghadapi karakter jemaah haji seperti ini $\mathrm{KBIH}$ harus pula memiliki cara dan strategi tertentu. Karena kalau karakter jemaah seperti ini dibiarkan, bisa merusak suasana dan iklim dalam rombongan jemaah di KBIH bersangkutan. Penangananannya biasanya oleh pembimbing yang sudah berpengalaman atau langsung dihadapi oleh pimpinan atau pemilik KBIH. Bahkan ketika pada titik puncak, kalau sudah diingatkan tetap berperilaku seperti itu, KBIH membiarkannya pasrah pada Allah SWT, dan membiarkan agar Allah SWT yang langsung menegurnya.

Menghadapi karakteristik dan tipe jemaah yang heterogen ini, tentu tidak hanya dibutuhkan skill dan kompetensi yang bagus mengenai ajaran agama, peraturan, dan hal ihwal mengenai penyelenggaraan ibadah haji. Tetapi juga 
pengelola, pembimbing membutuhkan skill komunikasi yang baik. Karena tidak mudah mengarahkan, menunjukkan dan mengajak orang luar untuk tunduk, patuh, dan mau mentaati peraturan dan kebiasaan-kebiasaan yang sudah dilakukan lama di KBIH mengenai penyelenggaraan ibadah haji.

Pentingnya pembimbing dan KBIH memiliki komunikasi yang baik, juga diingatkan mengenai jangan sampai menyepelekan komunikasi oleh Ali Rokhmad (2016: 103), bahwa

Komunikasi dapat dipahami sebagai seni menyampaikan informasi (pesan, ide, gagasan) dari komunikator (KBIH) untuk mengubah serta membentuk perilaku komunikan (jemaah) (pola, sikap, pandangan dan pemahamannya) ke pola dan pemahaman yang dikehendaki komunikator $(\mathrm{KBIH})$. Karena itu, komunikasi adalah interaksi yang saling mempengaruhi satu sama lain, sengaja atau tidak disengaja, dengan melibatkan beberapa unsur yang tercakup di dalamnya, yaitu komunikator, komunikan, pesan, sarana, efek dan umpan balik.

Bagaimana cara agar komunikasi antara KBIH dengan jemaah berjalan baik dan efektif, bisa melihat paparan dari De Vito (dalam Rokhmad, 2016: 103-104), di antaranya:

Keterbukaan (openness), yaitu sikap dapat menerima masukan dari orang lain, serta berkenaan menyampaikan infomrasi penting kepada orang lain. Pihak KBIH siap menerima saran dan kritik dari jemaah. Hal ini agar jemaah merasa dekat dan tidak canggung ketika ada apa-apa dengan $\mathrm{KBIH}$;

Empati (empathy), yaitu kemampuan $\mathrm{KBIH}$ untuk merasakan kalau seandainya menjadi jemaah dapat memahami sesuatu yang sedang dialami jemaah, KBIH dapat merasakan apa yang dirasakan jemaah, dan dapat memahami sesuatu persoalan dari sudut pandang jemaah. Tidak hanya melalui kaca mata $\mathrm{KBIH}$, akan tetapi kaca mata jemaah;

Sikap mendukung (supportiveness) masing-masing pihak, baik KBIH maupun jemaah, yang berkomunikasi, memiliki komitmen untuk mendukung terselenggaranya ibadah haji yang baik dan sukses. Sikap mendukung dapat dilihat melalui sikap deskriptif bukan evaluative, spontan bukan strategik, provisional atau berpikiran terbuka, bersedia mendengar pandangan yang berlawanan dan bersedia mengubah posisi jika mengharuskan;

Sikap positif (positiveness) dikomunikasikan sedikitnya dalam dua cara, yaitu: menyatakan sikap positif untuk dirinya sendiri (KBIH), dan secara positif mendorong orang menjadi teman berinteraksi kepada para jemaah $\mathrm{KBIH}$;

Kesetaraan (equality). Jangan ada perbedaan status dan posisi antara KBIH dan jemaah. Pergunakan bentuk komunikasi antarpribadi ketika bicara pada jemaah satu atau dua orang, karena itu akan lebih efektif bila suasananya setara. Akui secara diam-diam bahwa jemaah bernilai dan berharga di mata $\mathrm{KBIH}$, dan bahwa masing-masing posisikan sebagai pihak yang mempunyai sesuatu yang penting untuk disumbangkan.

Kalau melihat kenyataan di lapangan, dari beberapa informan sebagai 
perwakilan dari KBIH, bahwa KBIH memiliki input ada yang kurang memenuhi standar ideal sebuah input untuk sebuah lembaga, organisasi dan perusahaan. Namun ada juga KBIH yang sudah memenuhi unsur input harapan ini, yaitu memiliki visi, misi, dan tujuan KBIH yang terpampang di kantor.

Untuk kebanyakan KBIH yang tidak memiliki visi, misi dan tujuan yang jelas apalagi sampai tertulis, dalam praktiknya setiap $\mathrm{KBIH}$ bertujuan ingin membantu jemaah untuk meraih haji mabrur yang dalam perjalanannya ketika berhaji mulai dari persiapan, pemberangkatan, pelaksanaan di tanah suci dan pulang kembali ke tanah air, tidak ada kendala, masalah dan lain sebagainya.

Mengenai KBIH yang harus memiliki visi, misi dan tujuan, sebagaimana sudah di atur dalam ketentuan pasal 2 UU Nomor 13 tahun 2008 yang menyatakan bahwa asas penyelenggaraan ibadah haji adalah pertama, keadilan. Keadilan dimaknai sebagai tindakan memperlakukan jemaah yang sama atau tidak berat sebelah dalam memberikan pelayanan. Kedua, profesionalitas, penyelenggarakan ibadah haji senantiasa mempertimbangkan pengetahuan, keahlian, dan pengalaman petugasnya. Ketiga, akuntabilitas. Penyelenggaraan ibadah haji bersifat terbuka dan dapat dipertanggungjawabkan secara etik dan hukum dengan prinsip tidak semata mencari keuntungan.

Meskipun ada KBIH yang tidak memiliki visi, misi dan tujuan yang jelas, namun mereka sudah mempraktikkan ketentuan penyelenggaraan haji yang diatur dalam Pasal 2 UU Nomor 13 tahun 2008. Para KBIH ini berlaku adil pada jemaah, terutama ketika ada jemaah yang tidak mampu membayar uang manasik tetap saja mereka bisa ikut manasik haji. Kemudian KBIH ini pun tetap professional dan betanggungjawab dengan menjalankan tugasnya, misalnya ketika ada jamaah yang tetap tidak mampu memenuhi harapan baik setelah manasik haji, para pembimbing dengan sabar, telaten, dan niat ingin membantu jemaah meraih haji mabrur. Termasuk ketika ada jemaah yang sakit, tersesat, dan permasalahanpermasalahan yang biasa terjadi di lapangan yang tidak ada di manasik haji. Para KBIH ini bertanggungjawab sepenuhnya terhadap jemaah haji.

Hal yang sama pun dikatakan Ali Rokhmad, bahwa penyelenggaraan ibadah haji memiliki prinsip sebagai dasar pemikiran yang melandasi kerja setiap $\mathrm{KBIH}$, yaitu:

Mengedepankan kepentingan jemaah. Kepentingan jemaah merupakan prinsip dasar yang utama sebagai hak jemaah haji. Prinsip ini harus diusung oleh setiap KBIH menunjukkan kewajiban yang tidak sekadar memberikan layanan, tetapi lebih mengedepankan kepentingan jemaah. Juga bukan sekadar mengejar terpenuhinya standar pelayanan minimal, lebih dari itu capaian kinerja terbaik yang harus diraih $\mathrm{KBIH}$ ialah menuju kepuasan pelanggan (customer satisfaction), yaitu jemaah haji itu sendiri. Dengan mementingkan jemaah sehingga jemaah menjadi puas dengan pelayanan yang diterima jemaah, maka jemaah .

Memenuhi rasa keadilan. Dalam penyelenggaraan ibadah haji, keadilan diimplementasikan dengan memberikan layanan sesuai hak jemaah tanpa 
mengurangi sedikit pun oleh KBIH kepada para jemaahnya. Ada KBIH yang tidak berbuat adil pada para jemaahnya. Seperti jemaah yang terlantar, mulai dari tempat tinggal di hotel, makannya selama di tanah suci, dan transportasi yang tidak layak sama sekali.

Memberikan kepastian. Kepastian keberangkatan bagi jemaah haji harus diinformasi oleh KBIH. KBIH harus memperlakukan kepada para jemaah haji yang telah memenuhi syarat dan masuk kuota tahun berjalan harus diberangkatkan, tidak ada alasan karena penerbangan atau kesalahan administrasi. Termasuk kebijakan sistem sewa pesawat dilakukan dalam rangka memperoleh kepastian layanan penerbangan saat keberangkatan dan kepulangan jemaah haji. Para KBIH kepada jemaah haji yang diberangkatkan ke Arab Saudi, dipastikan siap memperoleh layanan transportasi, akomodasi, konsumsi dan kesehatan. Khusus untuk kepastian keberangkatan jemaah haji, seringkali jemaah haji dirugikan oleh $\mathrm{KBIH}-\mathrm{KBIH}$ yang bertujuan mencari keutnungan sendiri dengan mengorbankan para jemaah. Dengan motif harga dan ongkos haji yang lebih murah dari $\mathrm{KBIH}$ lain, tetapi tidak ada kejelasan mengenai waktu pemberangaktan. Bahkan ada di antara jemaah yang kecewa karena tidak kunjung berangkat sementara uang sudah banyak dikeluarkan.

Mengedepankan sahnya ibadah. Penyelenggaraan ibadah haji pada dasarnya merupakan rangkaian perjalanan ibadah. Oleh karena itu, KBIH meskipun berbagai jenis layanan diberikan dengan baik, namun apabila aspek ibadahnya tidak mendapatkan perhatian serius, sehingga ibadah hajinya kurang memenuhi ketentuan manasik dengan baik, maka tidak akan banyak memperoleh manfaat dari hajinya. KBIH harus bertanggungjawab akan hal ini, karena ini urusannya dengan sahnya ibadah. Namun demikian, masih ada KBIH yang mengkomersilkan ibadah haji ini. sahnya ibadah haji selalu dikesampingkannya.

Efisien dan transparan. Prinsip efektif dan efisien dalam menyelenggarakan haji lebih difokuskan pada pengelolaan uang dari jemaah. Misalnya pengadaan barang dan jasa yang dilakukan KBIH, baik di tanah air maupun di Arab Saudi yang terus diberikan kepada jemaah. Kalaupun menggunakan dana jemaah yang tersisa di KBIH, sebaiknya diinfokan kepada jemaah seperti yang dilakukan KBIH Khairul Ummah Jakarta Utara dan KBIH Ar Rahmah Palembang, ketika ada dana sisa akan diumumkan ke jemaah setelah pulang dari ibadah haji. Selain itu, dibicarakan rencana penggunaan dana sisa tersebut untuk kepentingan umat dan publik. Pemanfaatan biaya operasional haji untuk memberikan pelayanan semaksimal mungkin melalui peningkatan kuaitas jasa layanan dengan tetap pada prinsip efektif dan efisien. Mengenai transparan ini, banyak KBIH yang tidak transparan dalam pengelolaan dana manasik haji, bahkan ada beberapa KBIH yang meminta dana lebih untuk biaya operasional manasik haji ini.

Nirlaba. Penyelenggaraan ibadah haji yang dilaksanakan oleh KBIH harus dilandasi prinsip nirlaba. Maksudnya tidak mencari keuntungan (non profit), tetapi mementingkan pelayanan (service oriented). Ini yang sering dilakukan pula oleh 
KBIH-KBIH yang melaksanakan tugas dan fungsinya semata-mata ikhlas dan mendapat pahala dari Allah SWT. Namun demikian, meskipun mereka tidak mengutamakan keuntunga, tetapi pada praktiknya mereka senantiasa mendapat imbalan yang tidak disangka-sangka. Ibadah haji merupakan ibadah haji yang bisa menguntungkan. Banyak peluang bisnis dan usaha dari penyelenggaraan ibadah haji ini. Termasuk para pengelola KBIH seringkali memanfaatkan peluang bisnis dalam penyelenggaraan ibadah haji, mulai dari pengayaan tas, pakaian, batik, dan berbagai pernak pernik yang berkaitan dengan haji.

Keterbukaan. Dalam penyelenggaraan ibadah haji, ada kewajiban $\mathrm{KBIH}$ untuk memenuhi hak jemaah, yaitu memperoleh informasi yang benar, jujur, dan tidak diskriminatif. Penyampaian informasi dilakukan dengan tetap memperhatikan perlindungan jemaah haji. Informasi disampaikan secara langsung atau tidak langsung, yaitu melalui media sosial dan lain sebagainya. Dengan adanya keterbukaan informasi ini, jemaah haji dapat memperoleh informasi hal ikhwal penyelenggaraan haji.

Selain prinsip dalam penyelenggaraan ibadah haji yang menjadi rujukan, mengenai visi dan misi dan tujuan KBIH pun layak dipertimbangkan. Karena visi, misi dan tujuan merupakan koridor dan batasan-batasan yang memagari langkah, gerak dan orientasi KBIH dalam menjalankan tugas dan fungsinya sebagai pembantu pemerintah dalam penyelenggaraan ibadah haji.

Visi, misi, dan tujuan merupakan hal yang sepele, ringkas, tidak membutuhkan modal dan tenaga untuk membuatnya. Tetapi keberadaan ini menjadi sesuatu yang sakral dan berkontribusi besar dalam pengembangan sebuah lembaga, organisasi atau perusahaan. Bahkan visi misi dan tujuan bisa dijadikan brand, karakteristik dan spirit lembaga atau perusahaan bersangkutan. Berangkat dari visi misi dan tujuan sebagai starting point dari terjadinya akselerasi dalam meningkatkan performa sebuah lembaga dan perusahaan.

Pentingnya visi misi dan tujuan dalam sebuah organisasi dan lembaga penting adanya seperti juga yang dikatakan Stephen P. Robbins dan Mary Coulter dalam Manajemen bahwa:

Setiap organisasi membutuhkan misi, yaitu sebuah pernyataan tentang tujuannya. Mendefinisikan sebuah misi akan memaksa manajer untuk mengidentifikasi apa yang harus dilakukan organisasi dalam menjalankan bisnis. Pernyataan dalam visi, misi dan tujuan memberi petunjuk mengenai apa yag dilihat oragnisasi sebagai tujuannya. Juga penting bagi manajer untuk mengidentifikasi tujuan dan strategi saat ini. Karena manajer akan mempunyai dasar untuk menilai apakah mereka perlu berubah atau tidak (Robbins \& Coulter, 2009: 215).

Sementara menurut Edward Sallis (2011: 215) bahwa sebagian besar organisasi menganggap penting adanya sebuah visi, misi dan tujuan. Bahkan di antara organisasi dengan jelas membedakan visi, misi, dan tujuannya. Pembuatan berbeda ini dengan maksud untuk memperjelas jenis organisasi seperti apa yang 
harapkan nantinya, dan memperjelas arah mana yang hendak diraih organisasi tersebut.

Dalam membuat visi misi, Edward Sallis (2011:216) memberikan penjelasan dan karakteristik yang harus dimiliki dalam visi misi, yaitu:

Visi itu mengisyaratkan tujuan puncak dari sebuah organisasi, dan untuk apa visi itu dicapai. Visi harus singkat, langsung dan menunjukkan tujuan puncak institusi. Sementara misi sangat berkaitan dengan visi dan memberikan arahan yang jelas, baik untuk masa sekarang maupun untuk masa yang akan datang. Statemen misi membuat visi memperjelas alasan kenapa sebuah institusi berbeda dari institusi-institusi lain.

Kemudian KBIH juga memiliki input perangkat, struktur organisasi yang mayoritas dari lingkungan keluarga seperti KBIH yang didirikan ketika sudah ada pondok pesantren yang tempat dan kantornya menginduk atau bersama-sama dengan bangunan pesantren. Ini banyak terjadi di beberapa KBIH yang ketua, pemilik atau pengelolanya adalah kiainya sendiri langsung. Maka otomatis struktur organisasinya pun tidak jauh dari keluarga dan kolega para kiai. Mulai dari pimpinan, pembimbing atau pembina $\mathrm{KBIH}$, posisi-posisi dalam $\mathrm{KBIH}$ akan diduduki oleh anak, mantu, adik, kakak, dan saudara-saudara kiai. Di sini kiai memiliki kendali dan kekuasaan penuh. Aturannya pun akan mengikuti aturan yang dibuat kiai, atau sesuai pemahaman, pengetahuan, dan keinginan kiai. Tanpa mengikuti aturan baku dari luar atau mengadopsi perangkat kerja dari luar.

Job desk atau gambaran tugas dan fungsinya pun sesuai dengan pengalamanpengalaman kiai ketika menjadi pembimbing, petugas haji, dan beraktivitas di dunia haji. Jangan berharap ada aturan tertulis yang mengikat para pengelola $\mathrm{KBIH}$, terlebih lagi keterangan-keterangan tugas dan fungsinya. Di sini lebih bersifat bekerja borongan, tidak sesuai dengan profesi dan keahliannya. Sebaliknya background pendidikan apa pun dituntut untuk memahami pekerjaan atau amanah yang diembannya.

Sementara KBIH yang tidak dipimpin oleh seorang kiai, kebanyakan $\mathrm{KBIH}$ yang berangkat dari organisasi keagamaan, seperti KBIH Lembaga Haji Muhammadiyah yang memiliki struktur organisasi lebih rapih dibanding KBIH di bawah yayasan pesantren. Namun tetap keberadaannya tidak independen, dan di bawah garis komando dan instruksi organisasi besarnya, yaitu Muhammadiyah. Petunjuk tugas dan arahan-arahan jelas dari organisasi besarnya. Adapun KBIH Lembaga Haji Muhammdiyah hanya sebatas operasional tentang haji dari Muhammadiyah, yaitu DPW Muhammadiyah Jawa Barat.

Dibandingkan dengan KBIH konvensional, yaitu KBIH yang di bawah pesantren yang secara pengelolaannya relatif normatif, KBIH yang di bawah organisasi keagamaan relatif lebih terjamin, tertata rapih tata pamong dan pengelolaannya. Ada petunjuk teknis dan job desk yang lebih jelas sehingga memudahkan para petugas KBIH Lembaga Haji Muhammadiyah.

Ada kelemahan dan kelebihan ketika para pengelola dan orang-orang yang 
ada dalam struktur organisasi KBIH adalah orang terdekat, saudara, anak dan mantu. Akan jauh bicara professional dalam pengelolaannya. Karena ada batasan kasih sayang, tidak berani menyalahkan, tidak berani bertindak dan menyuruh lebih tegas dan disiplin. Dampaknya adalah pada kinerja KBIH akan berjalan lambat. Beruntung kalau orang-orang yang duduk dalam struktur KBIH meskipun orang dekat dan keluarga, tetapi mereka tetap semangat bekerja, professional dalam menjalankan tugasnya. Bagaimana kalau kondisi dan situasinya berbeda. Kondisi ini akan memperuncing situasi dan suasana kerja dalam KBIH, terutama orang-orang yang dari luar ikatan darah pengelola KBIH.

Struktur organisasi menurut Robbins dan Coulter (2009: 239) merupakan susunan tugas-tugas formal di dalam suatu organisasi. Saat manajer menciptakan atau mengubah struktur, mereka terlibat dalam desain (perancangan) organisasi. Kurang lebih ada enam elemen yang harus ada dalam sebuah struktur organisasi, di antaranya: spesialisasi kerja atau pembagian kerja (division of labor), departementalisasi atau menghimpun pekerjaan-pekerjaan, rantai komando atau hierarki wewenang dari tingkat organisasi yang tinggi ke yang rendah, rentang kendali, sentralisasi dan desentralisasi, dan formalisasi.

Keenam struktur organisasi itu bisa dijadikan ukuran dalam membuat struktur organisasi dalam sebuah KBIH. Jangan sampai KBIH dikelola bertumpuk pada satu orang. Tetapi ada penyebaran dan pemerataan job dari pengelola jemaah haji. Selain untuk meningkatkan profesionalisme, juga untuk pemerataan beban dan tanggungjawab. Karena mengelola jemaah dalam penyelenggaraan ibadah haji, tidak hanya keterampilan, skill, dan kompetensi tetapi juga fisik yang kuat. Oleh karena itu, penting kiranya sebuah KBIH memiliki struktur organisasi yang handal dan professional sehingga biar lebih adil dalam bekerja, berjalan berimbang di antara para pengelola, jalannya roda organisasi KBIH tidak timpang.

Adapun mengenai peraturan-peraturan perhajian yang menjadi rujukan dasar KBIH dalam mengelola atau menyelenggarkan haji, semuanya merujuk pada peraturan-peraturan dan perundang-undangan perhajian yang sudah dibuatkan oleh pemerintah. Setiap KBIH ini hanya mengimplementasikan peraturan dan perundang-undangan tersebut. Terkecuali ada beberapa KBIH yang secara teknis membuat peraturan tersendiri yang sifatnya melengkapi peraturan yang dibuat pemerintah. Hal ini dilakukan karena tidak ada aturannya dari pemerintah. Meskipun tidak ada namun tetap peraturan dan perundang-undnagan pemerintah dijadikan barometer dan parameter ketika membuat peraturan $\mathrm{KBIH}$ sendiri. Namun lagi-lagi peraturan yang dibuat KBIH tidak ada yang tertulis dan jelas, lebih banyak lisan dan tugas-tugas instruksi langsung dari pemimpin atau pemilik KBIH.

Pada umumnya, peraturan yang biasa dibuat oleh $\mathrm{KBIH}$ ialah peraturan khusus kepada para jemaah KBIH bersangkutan, yang membedakan atau sebagai ciri khas jemaah KBIH yang satu dengan yang lainnya. Mulai dari peraturan tentang manasik haji yang diselenggarakan oleh $\mathrm{KBIH}$, peraturan-peraturan $\mathrm{KBIH}$ selama di perjalanan baik dari embarkasi, pesawat dan hotel misalnya 
menggunakan syal, gelang, peraturan ketika di tanah suci agar para jemaah KBIH tidak tersesat. Semua peraturan ini di luar peraturan pemerintah yang dibuat berdasarkan pengalaman ketika membimbing jemaah dalam penyelenggaraan jemaah haji.

Mengenai peraturan yang menjadi dasar dan rujukan dalam mengelola dan penyelenggaraan ibadah haji oleh $\mathrm{KBIH}$, bisa dilihat bagaimana lengkapnya peraturan-peraturan dan undang-undang yang sudah dibuatkan oleh pemerintah hampir di setiap tahunnya dalam rangka melancarkan, meningkatkan kualitas penyelenggaraan haji, di antaranya:

Pembagian kuota haji merujuk pada amanat Pasal 11 UU nomor 13 tahun 2008 bahwa menteri agama menetapkan kuota nasional, kuota haji khusus, dan kuota provinsi dengan prinsip adil dan proporsional. Pada pasal berikutnya menjelaskan bahwa gubernur dapat menetapkan kuota provinsi dan kuota kabupaten atau kota dengan mendasarkan rumus per mil jumlah penduduk muslim di kabupaten dan kota, dan masa tunggu jemaah haji di wilayah masingmasing;

Mengenai biaya haji merujuk pada Undang-Undang nomor 13 tahun 2008, pasal 21 ayat (1) menyatakan bahwa besaran biaya penyelenggaraan ibadah haji $(\mathrm{BPIH})$ ditetapkan oleh presiden atas usul menteri agama seteleah mendapat persetujuan DPR-RI. Sebelum memperoleh persetujuan dimaksud, dilakukan pembahasan komponen per komponen secara bersama antara kementerian agama dan komisi VIII DPR-RI. Sebelumnya, masing-masing membentuk panita kerja (Panja) BPIH dan melakukan sidang bersama-sama;

Peraturan tentang pembinaan ibadah haji dan umrah merujuk pada UndangUndang nomor 13 tahun 2008 tentang penyelenggaraan ibadah haji, pemerintah berkewajiban melakukan pembinaan ibadah haji dan umrah. Pembinaan diarahkan pada terwujudnya jemaah haji mandiri, yaitu kemampuan jemaah dalam memahami dan melaksanakan tata cara ibadah sesuai ketentuan syariat Islam;

Mengenai peraturan pembatalan jemaah haji merujuk pada peraturan menteri agama nomor 14 tahun 2012, pasal 11 menyatakan, pendaftaran haji dinyatakan batal, bila jemaah haji: meninggal dunia, mengundurkan diri karena alasan kesehatan atau alasan lain, tidak dapat berangkat dalam masa 2 kali musim haji, dilarang keluar negeri sesuai ketentuan perundang-undangan;

Peraturan mengenai pelayanan asrama haji embarkasi sebelum bertolak ke tanah suci jemaah haji ditampung di asrama haji embarkasi. Dalam PMA nomor 14 tahun 2012 pasal 34 dan 35 menyatakan bahwa pemerintah bertanggungjawab terhadap pelayanan akomodasi dan konsumsi jemaah haji selama di asrama haji embarkasi.

Kemudian merujuk pula pada peraturan pemerintah yang dibuat pada tahun 2013 mengenai Siskohat generasi kedua, Pemotongan kuota haji Indonesia sebesar 20 persen dari kuota dasar sebagai, dampak proyek perluasan Masjidil Haram, Migrasi Bank Penerima Setoran Biaya Penyelenggaraan Ibadah Haji dari Bank 
Konvensional ke Bank Syariah/Unit Usaha Syariah.

Pada tahun 2014 dilakukan sejumlah perbaikan regulasi dan tata kelola haji antara lain: Penetapan Undang-Undang Nomor 34 Tahun 2014 tentang Pengelolaan Keuangan Haji yang salah satu mandatnya adalah membentuk Badan Pengelola Keuangan Haji (BPKH) paling lambat September 2015.

Penggunaan kuota jamaah haji dilakukan secara transparan dan akuntable sesuai dengan urutan porsi, pelayanan akomodasi setara hotel berbintang 3, Upgrade bus shalawat yang beroperasion selama 24 jam untuk mengantar jamaah dari pemondokan ke Masjidil Haram. Penghematan biaya operasional penyelenggaraan haji dengan tidak mengurangi layanan kepada jemaah hajiSerta revitalisasi asrama haji.

Berdasarkan PMA nomor 3 tahun 2013 asrama haji embarkasi yang berada di bawah kementerian agama menjadi Unit Pelayanan Teknis (UPT) di bawah langsung direktorat jenderal penyelenggaraan haji dan umrah dan bertanggungjawab kepada direktur jenderal;

Pada tahun 2015 diterapkan sejumlah kebijakan yang diharapkan dapat membenahi pengelolaan haji, antara lain: implementasi total pelaksanaan pilot project e-hajj yang ditetapkan otoritas Arab Saudi, pengendalian daftar tunggu jamaah haji dengan memprioritaskan calon jemaah haji yang belum pernah melaksanakan ibadah haji dan mengimbau yang sudah berhaji untuk memberikan kesempatan kepada yang belum pernah berhaji karena haji wajib hanya sekali seumur hidup. Reformasi penyelenggaraan umrah, transformasi Asrama Haji menjadi Unit Pelaksanaan Teknis. Keterbukaan sistem sewa pemondokan, transportasi, katering dan pendukung lainnya dengan tidak mengurangi layanan kepada jemaah haji.

Selain itu, dilakukan penetapan Zona Integritas Wilayah Bebas Korupsi (WBK) dan Wilayah Birokrasi Bersih Melayani (WBBM). Mengenai rute merujuk pada peraturan yang dibuat pada tahun 2015 ini juga diterapkan rute baru keberangkatan dan pemulangan jamaah haji, dengan rincian: Gelombang I : Tanah Air -Madinah - Makkah - Jeddah - Tanah Air. Gelombang II : Tanah Air Jeddah - Makkah - Madinah - Tanah Air. Pada tahun 2015 juga diberlakukan penyediaan makan siang bagi jamaah haji selama di Makkah dan pematangan gagasan mempermanenkan pemondokan jamaah haji di Makkah.

Kemudian peraturan dan undang-undang mengenai penyelenggaraan ibadah haji yang dilaksanakan di Arab Saudi, pun setiap KBIH merujuk pada diatur dan disiapkan oleh pemerintah, mulai dari kedatangan haji di tanah suci, pelayanan transportasi darat selama berhaji di tanah suci, pelayanan kesehatan selama menjalankan ibadah haji, pelayanan petugas haji yang membantu pemerintah dalam menyelenggarakan badah haji, satuan operasional Armina, perlindungan jemaah dan petugas, afirmasi haji, pengawasan PIHK, dan hal-hal teknik perihal pemulangan jemaah haji.

Meskipun peraturan-peraturan yang sudah dibuatkan pemerintah relatif 
banyak, namun peraturan itu belum sepenuhnya mengcover persoalan-persoalan yang dihadapi KBIH dan jemaah dalam penyelenggaraan ibadah haji yang setiap tahunnya senantiasa lahir persoalan-persoalan baru. Peraturan dan perundangundangan itu sifatnya global, menyeluruh, tetapi tidak detil menyelesaikan persoalan jemaah di daerah dan lain-lain. Selain itu, dalam praktik dan pelaksanaan ibadah haji di lapangan, selalu ada saja penyimpangan dan pelanggaranpelanggaran terhadap aturan dan perundang-undangan. Baik yang dilakukan $\mathrm{KBIH}$ ataupun jemaah.

Kemudian mengenai manajemen input mutu rencana dan program $\mathrm{KBIH}$, berdasarkan data yang didapatkan di lapangan, bahwa tidak ada ukuran rencana dan program KBIH yang jelas dan ingin dicapai di kemudian hari. Namun secara angan-angan ada harapan dan rencana jangka panjang yang ingin diraih. Secara global, rencana dan program semuanya bermuara pada satu hal, yaitu ingin meningkatkan kualitas pelayanan pada jemaah, meningkatkan jumlah jemaah, membedakan antara KBIH satu dengan KBIH lainnya, keterjangkauan jemaah dari luar daerah sehingga mereka bisa bergabung dengan $\mathrm{KBIH}$ yang dianggap professional dan handal dalam melayani jemaah.

Meskipun tidak memiliki rencana dan program yang jelas, terukur, namun setiap KBIH setiap minggu, bulan, dan tahun ada kegiatan yang penuh. Namun semua hal itu berdasarkan pada rutinitas, insidental, tidak ada target dan capaiancapaian. Tidak ada rencana dan program-program yang rapih. Semua program hanya dalam angan-angan atau dibayangkan, tidak tertulis dan terpampang dalam sebuah kantor dan lain sebagainya.

Rencana dan program tidak hanya ada dan terekam dalam memori atau ingatan, tetapi harus ditulis, dirancang dan bisa diakses oleh para pengelola lainnya. Syukur-syukur dalam rancangan dan programnya selain bisa diakses dipahami oleh para pengelola KBIH. Hal ini bertujuan untuk menyadarkan akan tugas dan fungsinya dalam meraih setiap rencana dan program KBIH. Selain tertulis dan dipasang di kantor, rencana dan program ini ada penentuan waktu evaluasinya, dengan tujuan mengukur sampai di mana rencana dan program ini terealisasi. Kalau tidak terealisasi ketika waktu evaluasi, maka bisa diketahui faktor-faktor apa saja yang menghambat dan menjadikannya tidak tercapai rencana dan programnya.

Jauh kalau dibandingkan dengan lembaga atau perusahaan yang jauh lebih professional dalam membuat rencana dan program setiap tahunnya. Dengan pembuatan rencana dan program yang memakan waktu tidak sebentar. Ada agenda khusus yang dilakukan di akhir tahun sekalian rapat akhir tahun yang hasilnya menentukan rencana dan program di tahun yang akan datang. Sementara $\mathrm{KBIH}$ ini hanya sifatnya insidental dan sesaat, karena penyelenggaraan haji dilaksanakan setahun sekali. Jadi KBIH pun bekerjanya setahun sekali. Meskipun demikian, tetap saja KBIH harus memiliki rancangan perencanaan dan program yang matang menjelang pelaksanaan ibadah haji di tahun yang akan datang.

Mengenai rencana yang harus dimiliki setiap KBIH, menurut Edward Sallis, 
rencana ini tidak hanya rencana biasa, tetapi lebih dari itu, yaitu rencana strategis yang harus dimiliki KBIH. Rencana strategis kadangkala disebut rencana pengembangan usaha dari KBIH. Karena di dalam rencana strategis, akan merinci tolok ukur-tolok ukur yang kelak bisa digunakan KBIH dalam mencapai misinya (Sallis, 2011: 226).

Rencana strategis biasanya disusun dalam skala waktu di atas tiga tahun. Tujuannya adalah untuk memberi sebuah pedoman dan arahan kepada KBIH. Akan tetapi, rencana tersebut bukan merupakan instrumen yang kaku. Dalam situasi dan kondisi sekarang KBIH yang lebih kompetitif, rencana strategis adalah hal yang sangat penting. Tanpa rencana tersebut organisasi akan menjadi kurang terarah (Sallis, 2011: 226). Ibaratnya rencana itu peta yang mengantarkan KBIH ke tempat yang dituju. Kalau tidak menggunakan peta, maka KBIH akan kesasar ke tempat lain, sehingga sampainya pada tujuan akhir akan lebih lama. KBIH akan rugi dan banyak mengeluarkan dana yang tidak perlu.

Kemudian mengenai KBIH yang jarang memiliki program-program terukur dan dirancang dengan baik, Edward Sallis mengatakan bahwa kalau KBIH tanpa memiliki program yang tepat, KBIH tidak mungkin dapat mencapai tujuan yang telah ditetapkannya. Kalau KBIH tidak memiliki program yang membantunya dalam meraih pasar yang ditargetkan, maka jelas KBIH tersebut membutuhkan sebuah startegi dan skala waktu untuk mengembangkannya. Pengembangan tersebut tidak hanya akan mencakup program-program baru, namun juga mencakup cara baru dalam fleksibel dalam menjalankan program yang sebelumnya sudah ada (Sallis 2011: 227).

Lebih lanjut Edward Sallis (2011: 227-228) menjelaskan, bahwa ada tiga strategi pemasaran umum yang bisa dilakukan oleh setiap KBIH. Pertama, strategi biaya rendah. Strategi ini menuntut KBIH untuk menjadi institusi yang memiliki biaya paling rendah dalam pasarnya. Strategi ini murah dan praktis dipakai oleh KBIH. Mudah dilakukan karena KBIH sesungguhnya tidak membutuhkan modal besar dalam membuat strategi, karena pada prinsipnya $\mathrm{KBIH}$ adalah fasilitator yang membantu pemerintah. Kedua, strategi pembedaan, yaitu strategi yang menuntut $\mathrm{KBIH}$ untuk menjadi unik dalam beberapa hal, dibandingkan dengan para pesaingnya. Dan ini sesungguhnya KBIH di Indonesia sudah memiliki keunikan yang disesuaikan dengan daerah, latar belakang pendirian KBIH yang biasanya dari yayasan dan pondok pesantren atau lembaga keagamaan. Ketiga, strategi fokus. Strategi ini mencakup konsentrasi pada sebuah wilayah geografis, kelompok pelanggan, atau segmen pasar tertentu. Ini sudah dibentuk oleh $\mathrm{KBIH}$ di Indonesia yang memiliki heterogenitas sangat tinggi, karena mereka berada di beberapa daerah yang juga memiliki karakter kedaerahan yang khas. 


\section{PENUTUP}

Berdasarkan paparan di atas, bahwa manajemen mutu input KBIH di Indonesia, yang diwakili KBIH Jawa Barat, KBIH Jakarta, dan KBIH Palembang, memiliki input yang masih tergolong konvensional. Setiap KBIH belum menyadari akan pentingnya input dalam membangun sebuah KBIH yang berkualitas dengan standar tinggi. Dalam pengelolaan input pun relatif berjalan apa adanya, dan tetap berprinsip yang penting jemaah puas ketika melakukan bimbingan dan pelaksanaan haji, jemaah tetap banyak daftar ke KBIH.

Hasil dari penelitian ini, sekiranya menarik meneliti untuk lebih lanjut mengenai tema manajemen mutu input, misalnya bagaimana dampak pelatihanpelatihan manajemen mutu yang diterima para pengelola $\mathrm{KBIH}$, dan evaluasi sistem input manajemen mutu KBIH. Karena meneliti tentang manajemen mutu $\mathrm{KBIH}$ akan tetap menarik, seiring dengan semakin kompleksnya dinamika penyelenggaraan ibadah haji dari tahun ke tahun.

\section{DAFTAR PUSTAKA}

Gharakhani, D., Rahmati, H., Farrokhi, R. M., \& Farahmandian, A. (2013) Total Quality Management and Organizational Performance, American Journal of Industrial Engineering, 2013, Vol. 1, No. 3, 46-50.

Nuryati, S. (2017). Evaluasi Implementasi Sistem Manajemen Mutu ISO 9001:2008 di Puskesmas Wilayah Kabupaten Sleman, JMMR Jurnal Medicoeticolegal dan Manajemen Rumah Sakit), 6 (2): 140-157.

Robbins, S. P. \& Coulter, M. (2009). Manajemen, Edisi Kesepuluh Jilid 1, Jakarta: Erlangga.

Rokhmad, A. (2016). Problematika Penyelenggaraan Ibadah Haji: Studi Kasus Haji di Dalam dan Di Arab Saudi, Jakarta: Kementerian Agama RI Direktorat Jenderal Penyelenggaraan Haji dan Umrah.

Rokhmad, A. (2016). Character Building Pembimbing Manasik Haji: Modul Sertifikasi Pembimbing Manasik Haji, Jakarta: Kementerian Agama RI Direktorat Jenderal Penyelenggaraan Haji dan Umrah tahun 2016.

Sadikoglu, E. \& Olcay, H. (2014). The Effects of Total Quality Management Practices on Performance and the Reasons of and the Barriers to TQM Practices in Turkey, Hindawi Publishing Corporation Advances in Decision Sciences, Volume 2014, 1-17.

Sallis, E. (2011). Total Quality Management in Education: Manajemen Mutu Pendidikan, cet. Ke-Yogyakarta: IRCiSoD. 